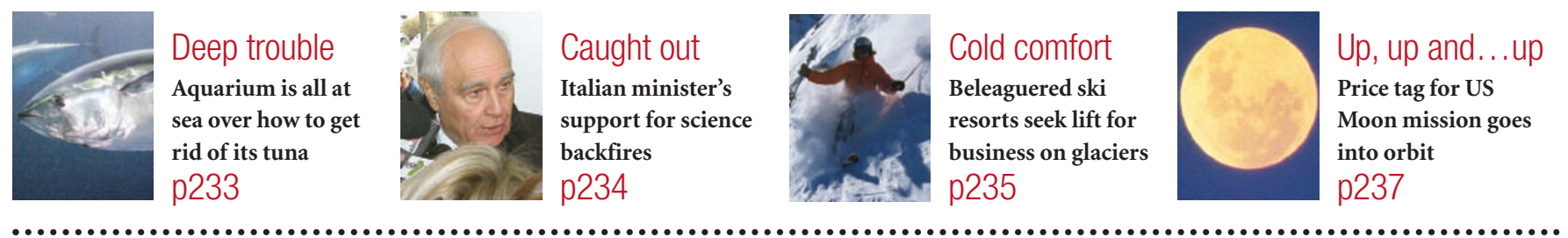

\title{
Security restrictions lead foreign students to snub US universities
}

Geoff Brumfiel, Washington

The number of foreign graduate students admitted to top US research institutions has declined precipitously this year, according to data released on 7 September.

Admissions from China, by far the largest source of foreign scientists in the United States, fell by a third this year, compared with 2003, according to the Council of Graduate Schools. The council surveyed 126 institutions, including leading private and public research universities in the United States.

The numbers appear at a time when government officials are pledging to reform a visa system that, most observers agree, has created mounting difficulties for incoming students and researchers since the terrorist attacks of 11 September 2001. And both President George Bush and Democrat candidate John Kerry have told Nature that if they win November's election they will take steps to ensure that foreign scientists are made welcome in the United States (see page 238).

The survey showed a $19 \%$ decrease in the number of foreign students admitted to graduate programmes in the life sciences and a $17 \%$ drop in admissions in the physical and Earth sciences. Admissions from China, India and South Korea, which between them provide the lion's share of foreign graduate students in the United States, were all down sharply (see graph, right).

The report seems to back up years of complaints from academics and administrators that US security procedures are hurting the country's ability to attract graduate students from around the world (see Nature 427, 190-195; 2004).

The survey, which measures the number of students actually admitted to US schools - as opposed to the number of applications received - is the first concrete evidence that fewer foreign graduate students are coming this year, says Heath Brown, director of research and policy analysis at the Washington-based council.

"I think that it points to a very serious problem," says Peggy Blumenthal, vice-president for educational services at the Institute of International Education in New York. Blumenthal says that new immigration rules

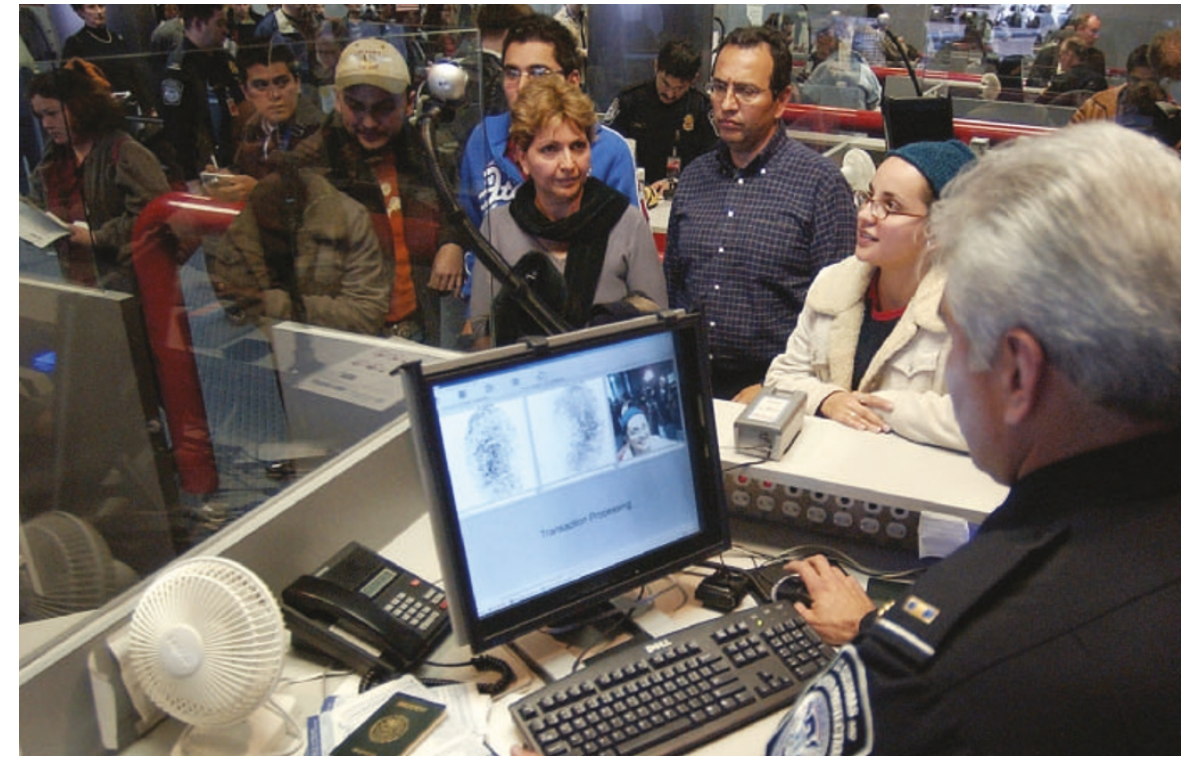

Clamp-down: mounting security controls at US entry points may be deterring foreign graduates.

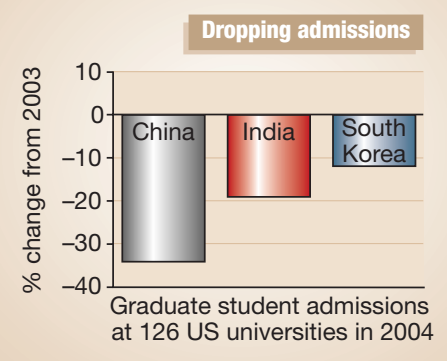

introduced after the 11 September attacks are partly to blame for the decline. These require foreign scientists to undergo security checks with more than one US agency. The checks, along with required interviews and a new Department of Homeland Security student-tracking system, have caused lengthy delays for some visitors.

Just two days after the study was released, government officials told Congress that they were trying to reduce waiting times. "We have made great progress in improving the interagency security-clearance process in recent months by moving from a paper-based system to electronic transmission," said Janice Jacobs, head of visa services at the Depart- ment of State. Stewart Verdery, assistant secretary for border security at the Department of Homeland Security, added that his agency was working with the state department to extend security clearances granted to foreign students and scientists to more than a year. "We are looking at ways to make the visa application process smoother," he said.

Wendy White, head of the international office at the National Academy of Sciences, calls the proposed changes "terrific" but says that she would like to see more details about how and when they will be implemented. She adds that her office is still averaging more than 100 complaints every month from scientists who are experiencing delays.

Tough economic conditions in some states, including California, have led to overall reductions in the number of graduate students admitted at public universities, says Brown, and domestic graduate student enrolment is also down, by $5 \%$.

Blumenthal says that it is too early to tell whether the planned reforms will be enough to reverse this year's decline in student enrolment from abroad. "Whether this is a blip or a trend, we just don't know yet," she says.

www.cgsnet.org 